Document downloaded from:

http://hdl.handle.net/10251/125664

This paper must be cited as:

Rosello Caselles, J.; Soriano Martinez, L.; Savastano, H.; Borrachero Rosado, MV.; Santamarina Siurana, MP.; Paya Bernabeu, JJ. (2018). Microscopic chemical characterization and reactivity in cementing systems of elephant grass leaf ashes. Microscopy and Microanalysis. 24(6):593-603. https://doi.org/10.1017/S1431927618015192

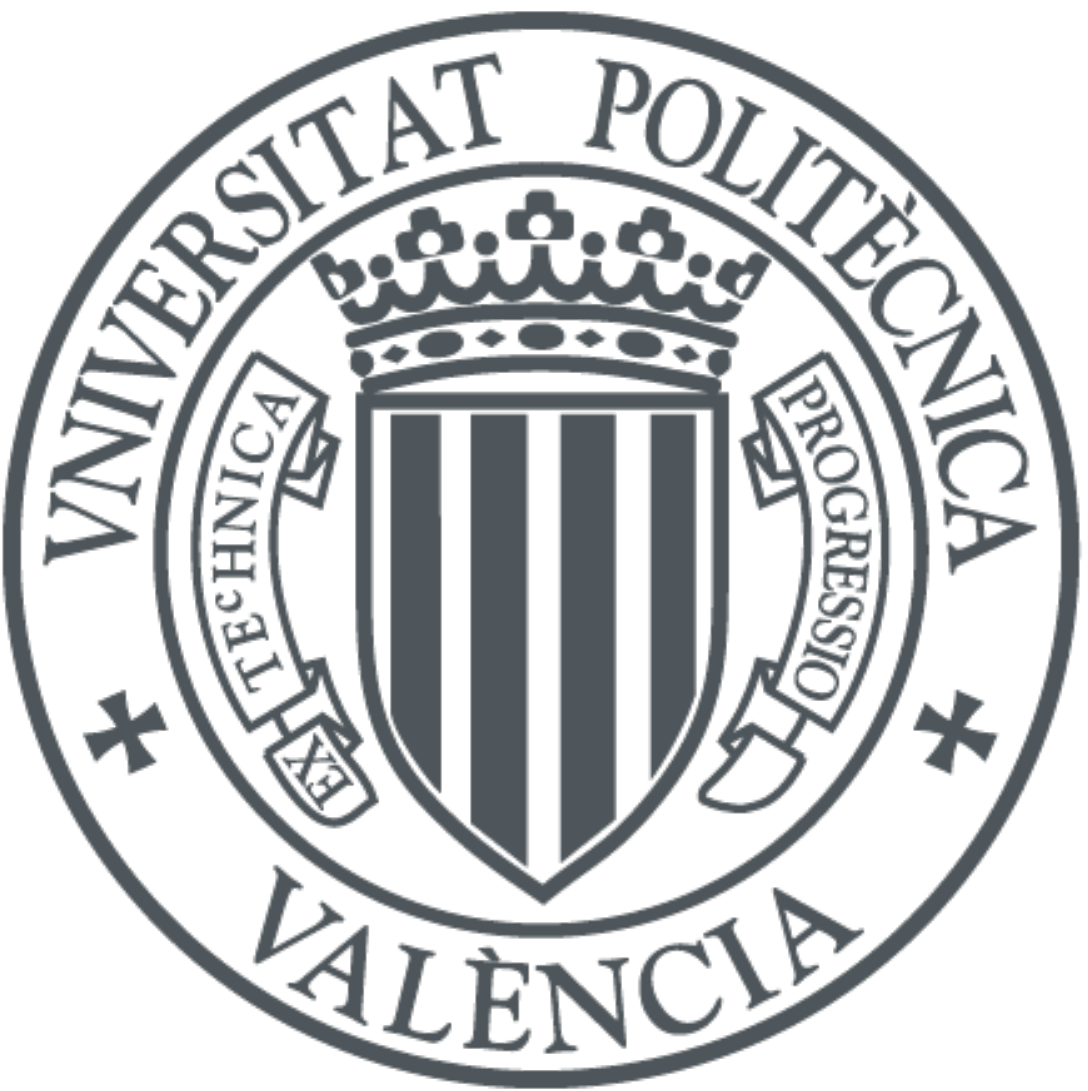

The final publication is available at

http://doi.org/10.1017/S1431927618015192

Copyright Cambridge University Press

Additional Information 


\title{
MICROSCOPIC CHEMICAL CHARACTERIZATION AND REACTIVITY IN CEMENTING SYSTEMS OF ELEPHANT GRASS LEAF ASHES
}

\section{(Brief Title: Studies on Elephant grass leaf ash)}

\author{
Josefa Roselló 1,a , Lourdes Soriano2,b, Holmer Savastano Jr 3,c, M. Victoria Borrachero 2,d, \\ Pilar Santamarina ${ }^{1, \mathrm{e}}$, Jordi Payá ${ }^{2, f^{*}}$ \\ ${ }^{1}$ Departamento de Ecosistemas Agroforestales, Universitat Politècnica de Valéncia, \\ Valencia, Spain \\ ${ }^{2}$ Instituto de Ciencia y Tecnología del Hormigón (ICITECH), Universitat Politècnica de \\ València, Valencia, Spain \\ ${ }^{3}$ Departamento de Engenharia de Biossistemas, Faculdade de Zootecnia e Engenharia de \\ Alimentos, Universidade de São Paulo, Pirassununga, SP, Brazil \\ ajrosello@upvnet.upv.es, blousomar@upvnet.upv.es, cholmersj@usp.br, \\ dvborrachero@cst.upv.es, empsantam@eaf.upv.es, ${ }^{\mathrm{f}} \mathrm{j} j \mathrm{jpaya@cst.upv.es}$ \\ *Corresponding author (ijpaya@cst.upv.es Tel +34 963877564 Fax +34 963877569)
}

\section{Abstract.}

Many agrowastes are being used for energy production by combustion in power plants. This process generates huge amounts of ashes, which have a potential pozzolanic activity for blending with Portland cement or hydrated lime. In this paper, the ashes obtained from Elephant grass (Pennisetum purpureum Schum var. purple) leaves were studied: the silicon content and its distribution, the presence of other compounds, and additionally, the presence of silica bodies (phytoliths). Combustion temperatures of 450 and $650^{\circ} \mathrm{C}$ produced an unaltered inorganic skeleton (spodogram), whereas at $850^{\circ} \mathrm{C}$, there is a sintering process due to high potassium content in the ash. Phytoliths and different types of hairs were identified, and they contained high percentages of silica. Magnesium (mainly as periclase) was distributed in the most porous parts in the interior of the leaves. The silica can react with calcium hydroxide (pozzolanic reaction) forming calcium silicate hydrates (observed by Field Emission Scanning Electron Microscopy FESEM and thermogravimetric analysis TGA). Fixed lime percentages at 28 curing days (63\%) indicated the high reactivity of elephant grass leaf ashes in 
calcium hydroxide pastes due to the pozzolanic reaction. This study demonstrates the possibility of the reuse of ashes from elephant grass leaves for producing environmental friendly cements.

Keywords: silica, phytolith, spodogram, pozzolan, reactivity

\section{Introduction}

Supplementary cementing materials (SCMs) in the production of cements and concrete are widely studied by many researchers (Siddique \& Khan, 2011). The key of their use is due to, in many cases, the presence of amorphous silica and alumina in the compositions of SCMs. These SCMs are usually obtained as by-products or wastes from different human activities: industrial, agricultural, energetic and decontamination processes. Silica $\left(\mathrm{SiO}_{2}\right)$ and alumina $\left(\mathrm{Al}_{2} \mathrm{O}_{3}\right)$ amorphous phases are usually present in these wastes and they react with hydrated lime $\mathrm{Ca}(\mathrm{OH})_{2}$ by means of the pozzolanic reaction: this is the reason why this type of SCMs is called a pozzolan. This pozzolanic reaction yields hydraulic cementing products similar to those found in the hydration of ordinary Portland cement (OPC). The use of these SCMs in concrete leads to a reduction of OPC consumption, and additionally, avoids the disposition of wastes in landfills. From the technical point of view, the use of these pozzolans in OPC-based binders has advantages such as a lower heat of hydration, higher compressive strength and lower permeability/porosity of the capillary network. These advantages implies these pozzolanic materials could play an important role in the performance of concrete, specifically in its durability.

Global warming, which is attributed to the $\mathrm{CO}_{2}$ increase in the atmosphere, is becoming one of the most relevant worldwide issues (Barcelo et al., 2014). Portland cement fabrication is responsible of $5 \%$ of worldwide $\mathrm{CO}_{2}$ emissions, and consequently, another advantage in the use of SCMs from wastes is with respect to environmental concerns, i.e. the reduction of greenhouse gaseous (GHG) 
emissions. Agricultural wastes can be converted into potential power sources by combustion. This process converts biomass into water vapor, carbon dioxide and ashes, among others. $\mathrm{CO}_{2}$ emission has no net environmental impact because it is not of fossil origin. This carbon released during combustion was previously captured by plants in a recent period.

One of the products produced during combustion of biomass is the inorganic residue: ash. This ash must be collected from the boiler (bottom ash) or from the mechanical/electrostatic precipitators (fly ash). In both cases, the chemical nature of the ash could be interesting for blending with OPC. In many cases, ashes are rich in amorphous silica, which is a key reagent for achieving the pozzolanic reaction.

Different types of biomass ashes (Aprianti et al., 2015; Sata et al., 2012) are being studied for their reuse in OPC binders. The most well-known ash is that produced by combustion of rice husks. Rice husk ash (RHA) has been extensively analysed when mixed with OPC. Sugarcane bagasse ash (SCBA) and palm oil fuel ash (POFA) have also been tested in the last decade. However, there is an increasing interest on assessing the behaviour of new ashes from biomass (Payá et al., 2010; Aprianti, 2017) such as wood, bamboo leaves (Villar-Cociña et al 2011; Frías et al, 2012), bamboo stem (Rodier et al., 2017), coffee husks, cashew nut rinds (Lima \& Rossignolo, 2009), olive biomass (Beltran et al., 2016), banana leaves (Kanning et al., 2014), cocoa almond bark (Silva et al., 2015), sugarcane straw (Guzmán et al., 2011; Moraes et al., 2015) and corn cob (Adesanya \& Raheem, 2009) among others. A few studies have been also carried out by using ashes from elephant grass plants (Cordeiro \& Sales, 2015; Nakanishi et al., 2014a, 2014b, 2016; Cordeiro \& Sales, 2016). Elephant grass (Pennisetum purpureum) is cultivated for feeding ruminants; two cultivars are mainly grown: Napier and Cameroon. It grows rapidly (40 ton/ha/year) and it is considered as an efficient carbon dioxide sink (Lemus \& Lal, 2007). It can also be used in thermoelectric power plants as biomass source (Rocha et al., 2017). In this process, a huge amount of elephant grass ashes (EGA) is produced. Ash content in elephant grass is variable up to $8.1 \%$ in the leaves and up to $5 \%$ in the stem (Flores et al., 2012). 
The chemical composition (Cordeiro \& Sales, 2015; Nakanishi et al., 2014a, 2014b, 2016; Cordeiro \& Sales, 2016) of these ashes showed the high percentage of silica, and in some cases, also in alumina. $\mathrm{K}_{2} \mathrm{O}$ content was also important, although the percentage depends on the biomass treatment postburning. Table 1 summarizes the previously reported chemical composition of EGA. The ash produced by the biomass could be reused for fertilization of the grass field, thus diminishing external fertilizer inputs. Both $\mathrm{K}$ and $\mathrm{P}$ oxides are of interest to the fertilizer industry, and they could be removed without prejudice to the proposed use of the ashes as pozzolanic material. Two procedures have been proposed for removing these elements: by treating with hot water $(0.6 \mathrm{~g}$ ash by $\mathrm{mL}$ of water at $70^{\circ} \mathrm{C}$ during 30 minutes with continuous stirring, Nakanishi et al, 2014b) and by treating withy hydrochloric acid solution $\left(3 \% \mathrm{v} / \mathrm{v}\right.$, during $1 \mathrm{~h}$ at $90^{\circ} \mathrm{C}$, Nakanishi et at, 2014a). The extraction procedures for $\mathrm{K}$ and $\mathrm{P}$ are well known and could be attractive in light of the amount available in some of the results shown in Table 1. Then, the proposal of the ash reuse as pozzolanic material will not compete with other possible applications (such as fertilizers) if recovery of $\mathrm{K}$ and $\mathrm{P}$ could be carried out. Certainly, this recovery will yield some treated ashes with higher silica content, which is very appropriate in terms of reactivity in cement. When a pozzolan has a large percentage of compounds different than silica and alumina (in amorphous state), the extension of the pozzolanic reaction is limited, and less calcium hydroxide is chemically combined with the pozzolan. However, the presence of alkalis (e.g. potassium) could enhance the solubility of amorphous phases, producing a higher dissolution rate of the pozzolan. However in the case on the use of reactive aggregates, alkali silica reaction (ASR) would be favoured when a high content of alkalis are present in the cementing matrix (Nakanishi et al 2014b).

Table 1. Reported chemical compositions for EGA (\% by weight).

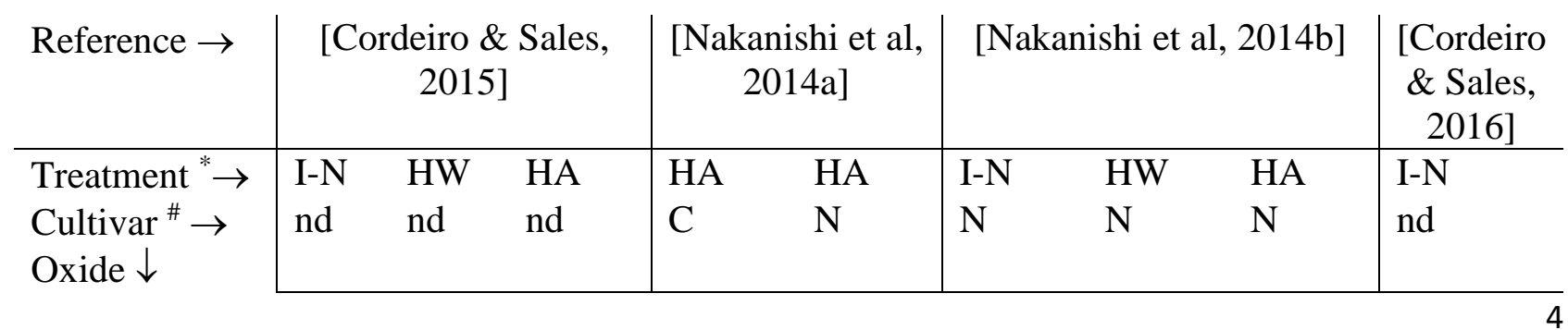




\begin{tabular}{l|lll|ll|lll|l}
$\mathrm{SiO}_{2}$ & 56.2 & 59.6 & 67.8 & 49.40 & 80.00 & 51.80 & 50.30 & 80.00 & 52.2 \\
$\mathrm{~K}_{2} \mathrm{O}$ & 7.4 & 3.5 & 2.0 & 8.60 & 7.05 & 22.00 & 17.7 & 7.05 & 4.9 \\
$\mathrm{Cl}$ & nd & nd & nd & 0.46 & 0.95 & 2.77 & 0.76 & 0.95 & nd \\
$\mathrm{CaO}$ & nd & 2.6 & nd & 10.40 & 1.85 & 5.68 & 6.72 & 1.85 & 2.8 \\
$\mathrm{MgO}$ & nd & nd & nd & 4.22 & 1.11 & 3.98 & 4.71 & 1.11 & nd \\
$\mathrm{P}_{2} \mathrm{O}_{5}$ & nd & nd & nd & 9.91 & 0.56 & 4.91 & 5.37 & 0.56 & 1.7 \\
$\mathrm{SO}_{3}$ & 2.3 & 1.8 & 1.6 & 0.47 & 0.65 & 2.82 & 0.64 & 0.65 & 2.0 \\
$\mathrm{Na}_{2} \mathrm{O}$ & nd & nd & nd & nd & nd & 0.18 & 0.16 & 0.11 & nd \\
$\mathrm{Fe}_{2} \mathrm{O}_{3}$ & 6.1 & 5.9 & 4.0 & 0.83 & 0.77 & 0.73 & 0.82 & 0.77 & 7.6 \\
$\mathrm{Al}_{2} \mathrm{O}_{3}$ & 22.1 & 22.1 & 23.1 & 0.47 & 0.44 & 0.60 & 0.72 & 0.44 & 22.7 \\
$\mathrm{LOI}$ & 4.4 & 3.0 & 2.6 & 14.60 & 6.31 & 4.22 & 2.76 & 6.31 & 4.4
\end{tabular}

* Treatments of the ash: I-N: In Nature; HW: Hot Water; HA: Hydrochloric Acid

\# Cultivar: C-Cameroon; N: Napier; nd: not determined

EGA presents similar pozzolanic activity to other biomass ashes, such as SCBA and RHA. This reactivity enables the preparation of $20 \%$ OPC replaced mortars by using these EGA, whose yielded compressive strength after 28 days of curing is similar to plain cement mortar. In another study (Aprianti, 2017), it was found that different cultivars yielded different ashes: the Napier variety produced higher silica rich ashes than the Cameroon variety (80\% vs $50 \%$ in $\mathrm{SiO}_{2}$ ). Both ashes obtained at $700^{\circ} \mathrm{C}$ showed high pozzolanic activity in EGA/Ca(OH $)_{2}$ systems: more than $80 \%$ of calcium hydroxide was fixed in $1: 1$ mixtures after 7 days of curing at $22^{\circ} \mathrm{C}$.

Plants absorb silicon from the soil as silicic acid and are deposited as amorphous hydrated silica or opal $\left(\mathrm{SiO}_{2} \cdot \mathrm{nH}_{2} \mathrm{O}\right)$ in the cell walls, inside the cells (intracellular spaces or cell lumen) and in the extracellular spaces of different plant organs such as leaves, pods, stems, inflorescences (i.e. herringbones) and epidermal appendages (trichomes) (Prychid et al., 2003). Different siliceous structures have been found in plants. There are special siliceous cells that are called phytoliths or silico-phytoliths (Piperno, 2006); they have a very particular shape.

The aim of this research is to study the ashes obtained from Elephant grass leaves in detail from the microscopic point of view, in order to analyse the silicon content and its distribution, the presence of other compounds, and additionally, the presence of silica bodies (phytoliths). Their leaves can be used for biomass power plants and the produced ash could be potential pozzolanic material for blending with OPC or for geopolymer design. 


\section{Experimental section}

Some leaf samples of elephant grass (Pennisetum purpureum Schum var. purple, EGL) were collected in Pirassununga (São Paulo, Brazil). To correctly identify structures rich in silica (phytoliths) and their location within the plant, studies on both collected material (dried) and ash resulting from combustion in a muffle furnace at selected temperatures were performed. Leaves were previously washed with deionized water.

Preparation of samples: a) Dried material studies: small samples of leaves were dried at $105^{\circ} \mathrm{C}$ for 24 hours in a laboratory oven (Memmert UN model); b) Calcined material (ash) studies: dried samples were calcined for 1 hour at the selected temperature $\left(450,650\right.$ and $850^{\circ} \mathrm{C}$ ) in a furnace (Carbolite RHF model 1500). The corresponding obtained Elephant grass ashes (EGA) were: EGA-450, EGA650 and EGA-850.

Microscopy equipment: Field emission scanning electron microscopy (FESEM) was used for microscopy and microanalysis studies using a ZEISS ULTRA 55 microscope. Samples for imaging were studied at an electron high tension of $1-3 \mathrm{kV}$ and were not coated (working distance 2.8-4.9 mm). Samples for chemical analysis using energy dispersive spectroscopy (EDS) were not coated and studied at $15 \mathrm{kV}$. The EDS analysis was carried out by analysing a $115 \mu \mathrm{m}$ x $85 \mu \mathrm{m}$ area with a working distance of 5.5-6.5 mm. The detector was an SDD X-Max 20 $\mathrm{mm}^{2}$ by Oxford Instruments. The software of processing was AZtec 3.3 SP1 by Oxford Instruments. The acquisition live time was $100 \mathrm{~s}$, and mean values and their standard deviations were calculated from 20 tests.

Reactivity studies: To study the pozzolanic reaction between EGA and calcium hydroxide, two tests were carried out. First, small parts of non-ground EGA were suspended in a $\mathrm{Ca}(\mathrm{OH})_{2}$ saturated solution at $65^{\circ} \mathrm{C}$ for 4 days, then the solid was carefully trapped, washed with acetone and dried at $65^{\circ} \mathrm{C}$ for 30 minutes. Second, $\mathrm{EGA} / \mathrm{Ca}(\mathrm{OH})_{2}$ pastes were prepared in 2:1 mass ratio (water/solid ratio of 0.8 ) and cured in sealed plastic containers for 9 and 28 days at room temperature. The EGA used was from a leaf sample calcined at $650^{\circ} \mathrm{C}$ for 1 hour and ground in an agate mortar. Hardened pastes 
were taken and ground in acetone to stop hydration reactions. Ground samples were dried at $65^{\circ} \mathrm{C}$ for 30 minutes. Thermogravimetric analyses were carried out by means a TGA-850 Mettler-Toledo thermobalance $\left(10^{\circ} \mathrm{C} \min ^{-1}\right.$ heating rate, nitrogen atmosphere, pinholed-lid sealed aluminium crucibles).

XRD studies: The mineralogical composition of EGA-650 was determined by X-ray diffraction (XRD, Brucker AXS D8 Advance), from $5^{\circ}$ to $70^{\circ} 2 \theta$ degrees with $\mathrm{Cu} \mathrm{K} \alpha$ radiation, working at 40 $\mathrm{kV}$ and $20 \mathrm{~mA}$.

\section{Results and Discussion}

Microscopic characterization of dried Elephant Grass Leaves (EGL). FESEM studies were carried out on EGL samples dried at $105^{\circ} \mathrm{C}$. Selected micrographs are shown in Figure 1. They show the upper leaf surface (adaxial surface, see Figs 1a, 1b and 1c) and the lower leaf surface (abaxial surface, see Figs 1d, 1e and 1f). A general view of the adaxial surface is depicted in Fig 1a: it shows many trichomes (hairs) randomly displayed; stomata are present among them. Fig 1b shows a detailed view of these epidermal cellular structures. Two types of hairs were identified: sharp short-thick (ts, 25-30 $\mu \mathrm{m}$ long, 18-22 $\mu \mathrm{m}$ wide) and long-thin (tl, $50 \mu \mathrm{m}$ long, 9-11 $\mu \mathrm{m}$ wide). Among these structures, some phytoliths are displayed (see Fig 1c): in these upper part, different morphologies for phytoliths are found: bilobated (dumbbell shape, p2), trilobated (p3) and tetralobated (cross-shape, p4). In the abaxial surface, other trichomes were found: in Figure 1d, aligned disposition of sharplarge trichomes (tsl, 90-100 $\mu \mathrm{m}$ long, 25-30 $\mu \mathrm{m}$ wide) on the nervadure of the leaf and holes (h) are randomly arranged among these aligned structures. These holes are the marks of some very long hairs (more than $600 \mu \mathrm{m}$ ) that were removed during the heating of the leaf. In Figure 1e, two types of trichomes are shown: large ones (tsl) in the nervadure position and, between nervadures, sharp shortthick (ts) trichomes are displayed. Many phytoliths are close to the largest trichomes, some of them 
among these hairs in aligned positions. Phytoliths of different shapes are also observed on this surface (see Figs. 1e and 1f).


Figure 1. FESEM micrographs of adaxial ( $a, b$ and $c$ ) and abaxial (d, e and $f$ ) surfaces of EGL dried at $105^{\circ} \mathrm{C}$. Key: s: stoma; ts: sharp short-thick trichomes; tl: long-thin trichomes; tsl: sharp-large trichomes; p2: bilobated phytolith; p3: trilobated phytolith; p4: tetralobated phytolith; h: hole from long hair.

Microscopic characterization of Elephant Grass leaf Ashes (EGA). FESEM studies were carried out on EGA samples obtained at $450^{\circ} \mathrm{C}, 650^{\circ} \mathrm{C}$ and $850^{\circ} \mathrm{C}$. Selected micrographs of EGA ashes obtained at $450^{\circ} \mathrm{C}$ are shown in Figure 2 (adaxial surface) and Figure 3 (abaxial surface). Figure 2a shows a general view of the spodogram obtained when a large part of organic matter has been 
removed by calcination at $450^{\circ} \mathrm{C}$. It can be observed that the structure remained, due to the presence of an important percentage of inorganic matter in the leaf. Many short-thick hairs (ts) are observed as well as aligned phytoliths (multiple chain, pc). These phytoliths are arranged in a similar way than those found in sugarcane leaves (Roselló et al., 2015), that is, they are aligned and arranged so that the major axis thereof is parallel to the major axis of the epidermal cells. Isolated phytolits are also maintained among the trichomes. Small holes are present which are related to stomata (s).

In Figure 2b, some phytoliths (bilobated p2 and tetralobated or cross-shape p4) are surrounded by an amorphous material, which belong to the remaining cells. This means that inorganic matter is also present in many types and parts of the cells.

In Figure 2c, two types of hairs ( $\mathrm{tl}$ and ts trichomes) are observed, suggesting the important inorganic content found in this cellular structures. In Figure 2d, a detailed view (see dotted rectangle in Figure 2c) of some randomly distributed trilobated and cross-shape phytolits are shown.
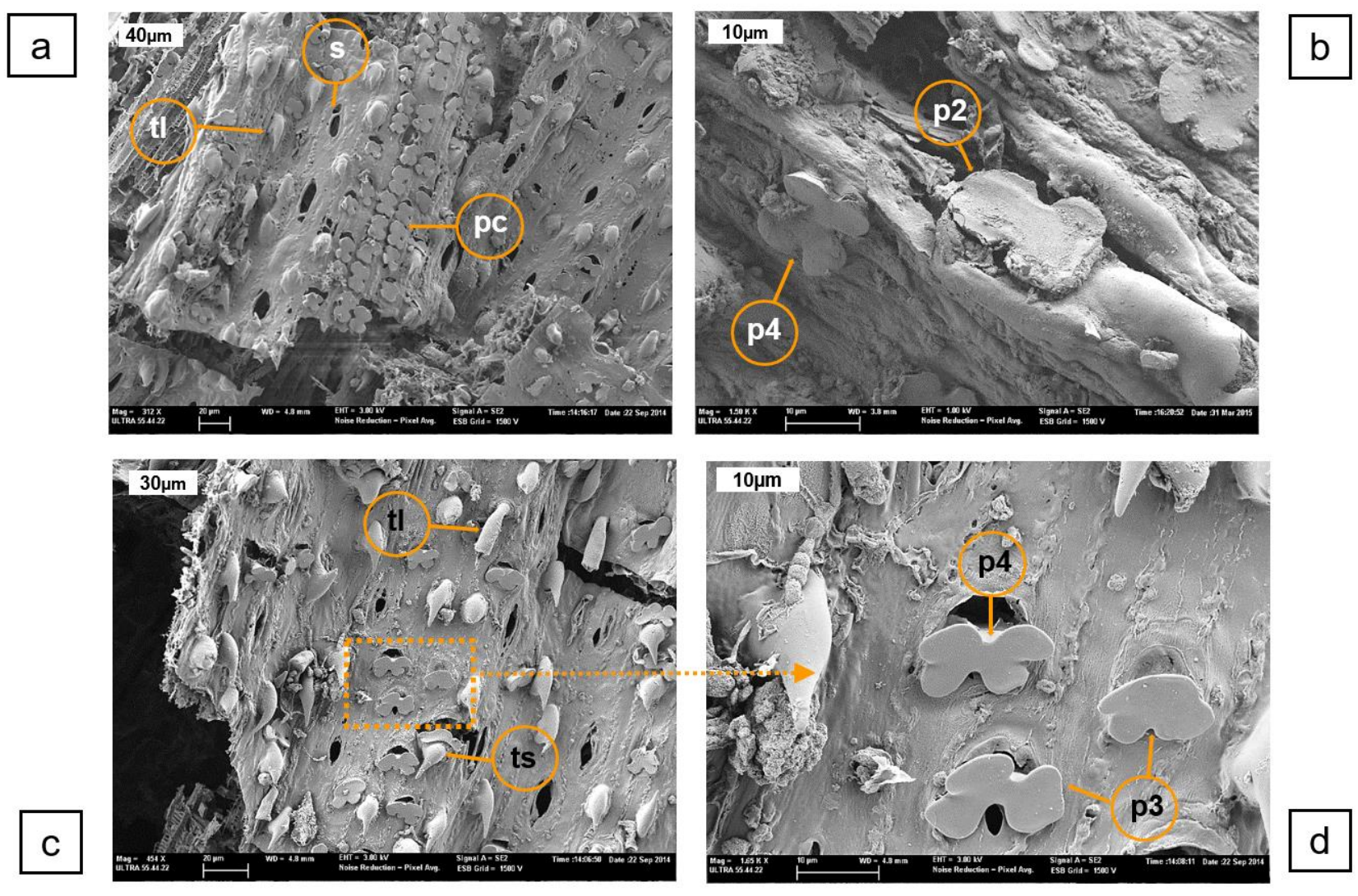
Figure 2. FESEM micrographs of EGA obtained at $450^{\circ} \mathrm{C}$ (adaxial surface): a) general view of the spodogram; b) Phytoliths surrounded of inorganic amorphous material; c) long-thin (tl) and shortthick (ts) trichomes in the adaxial surface; d) detailed view of isolated phytoliths (enlarged zone from Fig 2c marked with a dashed rectangle). Key: s: stoma; ts: sharp short-thick trichomes; tl: long-thin trichomes; p2: bilobated phytolith; p3: trilobated phytolith; p4: tetralobated phytolith; pc: phytolith chain.

Figure 3a shows a general view of the spodogram from the abaxial surface. In Figure 3b, the largest trichome which was identified on the dried leaf (Fig. 1e) are observed, suggesting again that these structures have an important inorganic content. Among these hairs, some phytoliths are aligned, which was also observed in the dried leaf (Fig. 1e). Surrounding these hairs, many phytoliths are displayed. In this side of the leaf, different shaped phytoliths are also observed, mainly cross-shape (tetralobated, p4, Fig. 3c) and dumbbell shape (bilobated, p2, Fig. 3d) phytoliths.
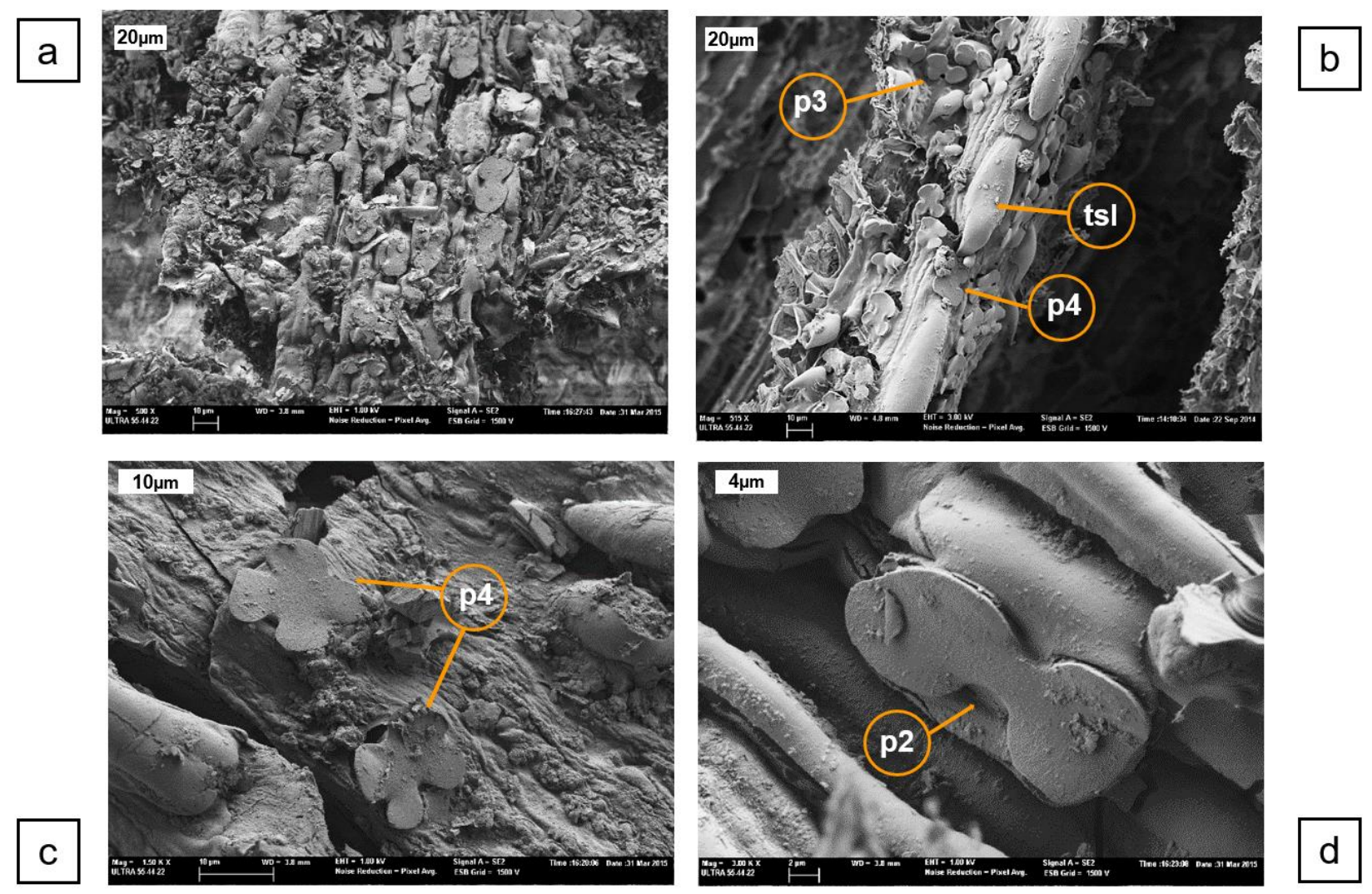

Figure 3. FESEM micrographs of EGA obtained at $450^{\circ} \mathrm{C}$ (abaxial surface): a) general view of the spodogram; b) larges trichomes (tsl) and p3 and p4 phytoliths surrounding them; c) tetralobated phytoliths (cross-shape, p4); d) bilobated phytoliths (dumbbell-shape, p2). 
When the leaves were ashed at $650^{\circ} \mathrm{C}$, the spodogram was maintained, suggesting the strong connected inorganic skeleton. Figure 4 shows some FESEM micrographs for EGA obtained at $650^{\circ} \mathrm{C}$. At this temperature, organic matter has been completely removed. Despite this, the spodogram was maintained (adaxial surface, see Figures 4a, 4b and 4c). In Fig. 4b, the remaining cellular walls (cw) from some elongated cells can be observed. In the abaxial surface (see Figs. 4d, 4e and 4f), some indications of partial fusion processes (sinterization) are observed: inorganic matter surrounding the phytoliths apparently melted during calcination. Most likely, localized higher temperatures than $650^{\circ} \mathrm{C}$ were reached because the heat emitted during the combustion of organic matter. However, phytoliths remain unaltered, probably due to the high content of silica (Roselló et al., 2015). 

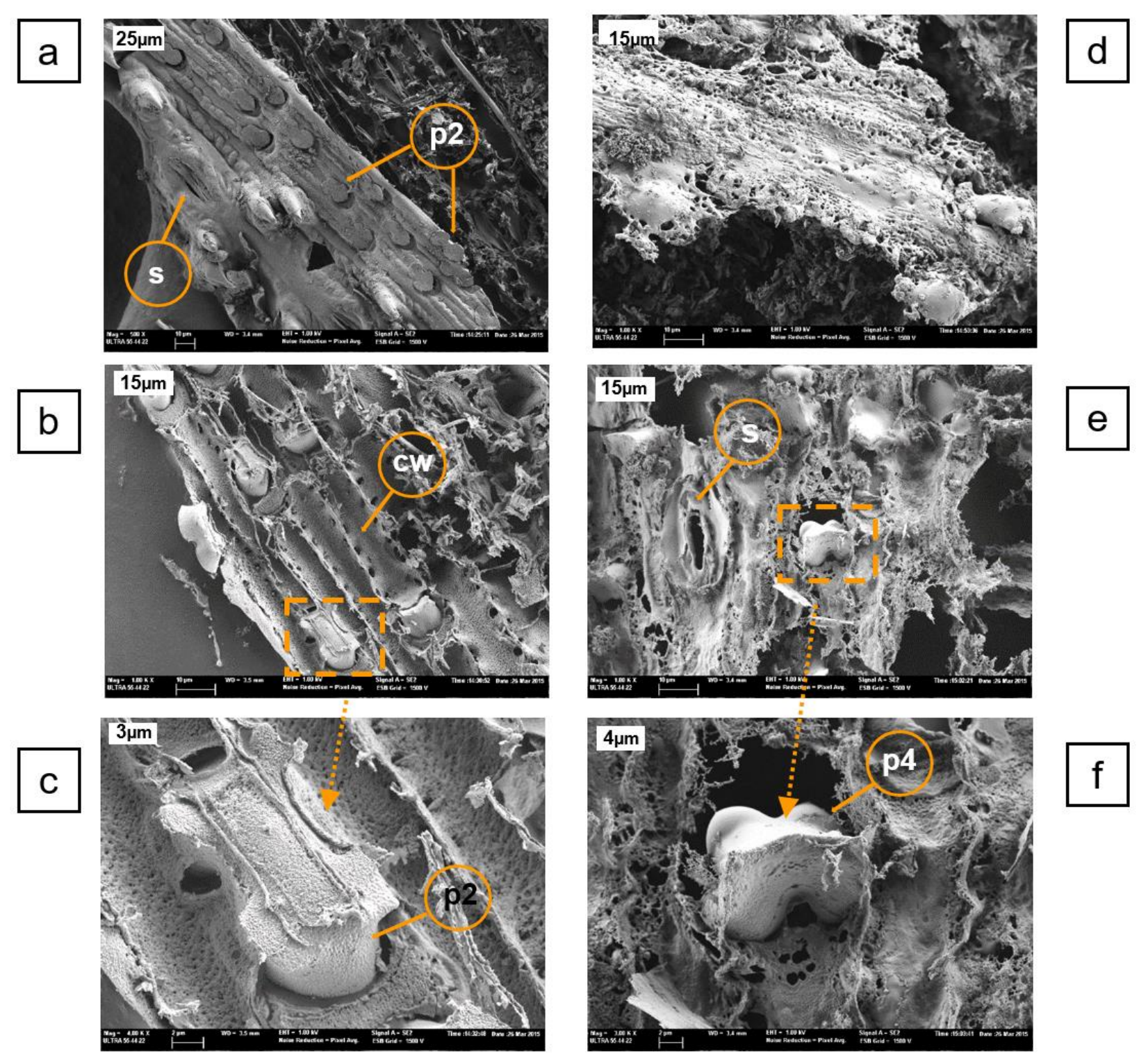

Figure 4. FESEM micrographs of EGA obtained at $650^{\circ} \mathrm{C}$ : a-c): adaxial surface (Figure $4 \mathrm{c}$ is an enlarged zone from Fig $4 \mathrm{~b}$ marked with a dashed rectangle); d-f) abaxial surface (Figure $4 \mathrm{f}$ is an enlarged zone from Fig 4e marked with a dashed rectangle). Key: s: stoma; p2: bilobated phytolith; p4: tetralobated phytolith; cw: internal part of the epidermis leaf, elongated cell walls.

To achieve a more pronounced sinterization process, EGA was obtained by heating at $850^{\circ} \mathrm{C}$. Figure 5 shows some micrographs of the spodogram. A compact and smooth surface was found (see Fig. $5 a)$, demonstrating the sinterization. Figures $5 \mathrm{~b}$ and $5 \mathrm{c}$ show a detailed view of the surface, in which crystallized zones appeared: the high temperature probably resulted in the transformation (Rivas $e t$ al., 2018) of amorphous silica into crystallized silica (probably cristobalite or tridimite) or the crystallization of potassium silicate (Hindryawati et al., 2014). It has been reported previously (de 
Souza et al., 2002) for rice husk ash that potash-rich silicate glass is produced in liquid phase, and which participates in the sintering process. Additionally, the presence of significant amounts of potash achieves the conversion of amorphous silica into cristobalite at temperatures higher than $800^{\circ} \mathrm{C}$ (Rivas et. al., 2018).


Figure 5. FESEM micrographs of EGA obtained at $850^{\circ} \mathrm{C}$ : a) General view; b) and c): texture of the surface (both are an enlarged zone from Fig 5a marked with dashed rectangles); d) detail of the crystalline formation.

Chemical composition of EGA. EDX analyses were carried out to quantify the chemical composition of EGA calcined at $650^{\circ} \mathrm{C}$. Twenty EDS spot data were taken on different zones from the same sample (approximately $10^{4} \mu \mathrm{m}^{2}$ area). Table 2 summarises the calculated compositions (carbon was not considered for the analyses). The highest percentage was found for $\mathrm{SiO}_{2}$, which denotes the siliceous nature of the ash. This percentage was found in the range of $26-86 \%$, with a mean value of $70.74 \%$. This percentage is notably lower than usual found for rice husk ash (Payá et 
al., 2010), and it is also lower than that found for bamboo leaf ash (Nakanishi et al., 2014a); however, it is significantly higher than the percentage found for sugarcane straw ash (Nakanishi et al., 2014a). Magnesium, calcium and potassium oxides were also high, and the low value for chloride (0-0.12\% range) is noted. Significant differences were found in the content of $\mathrm{Al}_{2} \mathrm{O}_{3}$ with values reported in the bibliography. Cordeiro \& Sales (2015) found percentages higher than $20 \%$ and Nakanishi et al. (2014a) detected values lower than 1\%. The results achieved in the present work are closer to the last case $(0.00-2.43 \%)$. A similar trend was found for $\mathrm{Fe}_{2} \mathrm{O}_{3}$. Samples analysed by Cordeiro \& Sales (2015) were most likely contaminated by soil particles. Samples for these reported studies (Cordeiro \& Sales, 2015, 2016) were taken from fields in which the soil was lateritic in nature: these soils are characterized by the dominance of kaolinitic clays and a residual accumulation of iron and aluminium oxides and hydroxides. The results in this work show that EGA is a good candidate to be a pozzolanic mineral addition in OPC mixtures. It may be important to consider the significant differences among ashes, depending on the source of leaves and the treatment process.

Table 2. EDS analyses (\% by weight) in Elephant Grass Ash (EGA) calcined at $650^{\circ} \mathrm{C}$ (carbon was not considered for the analyses).

\begin{tabular}{c|cccc} 
Oxide & $\begin{array}{c}\text { Mean } \\
\text { value }\end{array}$ & $\begin{array}{c}\text { Maximum } \\
\text { value }\end{array}$ & $\begin{array}{c}\text { Minimum } \\
\text { value }\end{array}$ & $\begin{array}{c}\text { Standard } \\
\text { deviation }\end{array}$ \\
\hline $\mathrm{SiO}_{2}$ & 70.74 & 85.99 & 26.25 & 12.27 \\
$\mathrm{~K}_{2} \mathrm{O}$ & 10.84 & 16.99 & 6.71 & 2.78 \\
$\mathrm{Cl}$ & 0.11 & 0.38 & 0.00 & 0.12 \\
$\mathrm{CaO}$ & 5.96 & 48.02 & 1.30 & 10.14 \\
$\mathrm{MgO}$ & 10.81 & 18.72 & 3.75 & 4.12 \\
$\mathrm{P}_{2} \mathrm{O}_{5}$ & 0.40 & 3.26 & 0.00 & 0.78 \\
$\mathrm{SO}_{3}$ & 0.43 & 4.74 & 0.00 & 1.05 \\
$\mathrm{Na}_{2} \mathrm{O}$ & 0.07 & 0.65 & 0.00 & 0.18 \\
$\mathrm{Fe}_{2} \mathrm{O}_{3}$ & 0.29 & 1.55 & 0.00 & 0.46 \\
$\mathrm{Al}_{2} \mathrm{O}_{3}$ & 0.34 & 2.43 & 0.00 & 0.69
\end{tabular}

EDS analysis on phytoliths (15 spot data, Table 3) shows that they are highly concentrated in silica: $98.06 \% \mathrm{SiO}_{2}$, and with very low amount of $\mathrm{K}_{2} \mathrm{O}(1.83 \%)$ and $\mathrm{MgO}(0.11 \%)$. In Figure $6 \mathrm{a}$, some of the analysed phytoliths are marked. Hairs are also very rich in $\mathrm{SiO}_{2}(93.92 \%$, Table 3), and some of the analysed hairs are marked in Figures $6 a$ and $6 \mathrm{~b}$. In the interior of the leaf (see Fig. 6c), two types 
of zones can be differentiated: denser zones which belong to the vascular bundle structures, and a more porous ones among them (see detailed view in Fig. 6d). Data in Table 3 reveals that there is a non-uniform distribution of the elements. Magnesium is one of the relevant compounds in the interior of the leaf, which is in the porous zone with a very high value of $73.23 \%$ as $\mathrm{MgO}$. In this zone, the silica content is very low (5.96\%) when compared to the global value $(70.74 \%$, Table 2$)$ or phytolith $(98.06 \%)$ or hair $(93.92 \%)$ compositions. $\mathrm{K}_{2} \mathrm{O}$ is present in higher concentration in the denser zone.

Table 3. EDS analyses (\% by weight) in selected parts of Elephant Grass Ash (EGA) calcined at $650^{\circ} \mathrm{C}$ (carbon was not considered for the analyses).

\begin{tabular}{|c|c|c|c|c|c|c|c|c|}
\hline \multirow[b]{2}{*}{ Oxide } & \multicolumn{2}{|c|}{ Phytoliths } & \multicolumn{2}{|c|}{ Hairs } & \multicolumn{2}{|c|}{$\begin{array}{l}\text { Internal leaf } \\
\text { porous zone }\end{array}$} & \multicolumn{2}{|c|}{$\begin{array}{l}\text { Internal leaf } \\
\text { denser zone }\end{array}$} \\
\hline & $\begin{array}{l}\text { Mean } \\
\text { value }\end{array}$ & $\begin{array}{l}\text { Standard } \\
\text { deviation }\end{array}$ & $\begin{array}{l}\text { Mean } \\
\text { value }\end{array}$ & $\begin{array}{l}\text { Standard } \\
\text { deviation }\end{array}$ & $\begin{array}{l}\text { Mean } \\
\text { value }\end{array}$ & $\begin{array}{l}\text { Standard } \\
\text { deviation }\end{array}$ & $\begin{array}{l}\text { Mean } \\
\text { value }\end{array}$ & $\begin{array}{l}\text { Standard } \\
\text { deviation }\end{array}$ \\
\hline $\mathrm{SiO}_{2}$ & 98.06 & 0.25 & 93.92 & 1.84 & 5.96 & 2.04 & 51.65 & 12.06 \\
\hline $\mathrm{K}_{2} \mathrm{O}$ & 1.83 & 0.16 & 4.51 & 1.23 & 3.16 & 0.67 & 12.87 & 1.89 \\
\hline $\mathrm{CaO}$ & - & - & & & 14.04 & 4.32 & 4.82 & 4.24 \\
\hline $\mathrm{MgO}$ & 0.11 & 0.19 & 1.57 & 0.82 & 73.23 & 7.56 & 28.68 & 9.89 \\
\hline $\mathrm{P}_{2} \mathrm{O}_{5}$ & - & - & & & 2.10 & 0.27 & 0.27 & 0.38 \\
\hline $\mathrm{SO}_{3}$ & - & - & & & 1.52 & 0.39 & 1.70 & 1.46 \\
\hline
\end{tabular}



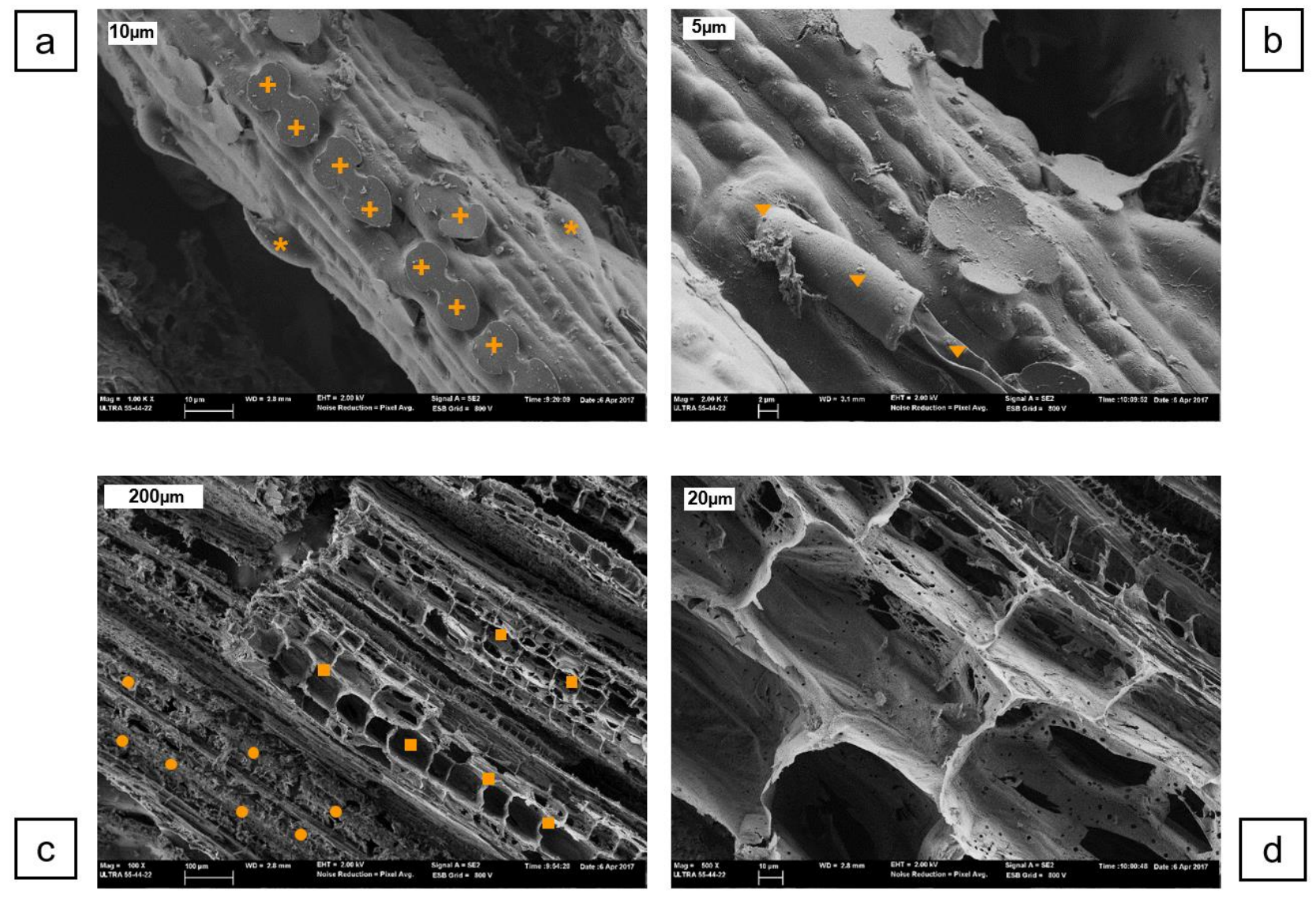

Figure 6. FESEM taken for EDS analyses on selected parts of EGA calcined at $650^{\circ} \mathrm{C}$ : a) phytoliths (marked with + ) and short hairs (marked with *) in EGA for EDX analyses; b) long hair (marked with $\boldsymbol{\nabla}$ ); c) internal part of the leaf showing porous zones (analyses marked with $\boldsymbol{\square}$ ) and denser zones (analyses marked with $\bullet$ ); d) detail of porous zone.

Reactivity of EGA to calcium hydroxide: EGA-650 particles after reaction (taken from a saturated calcium hydroxide solution after 4 days at $65^{\circ} \mathrm{C}$ ) were microscopically studied. Figure 7 shows several micrographs of the reaction products. In general, the reaction produces a gel coating composed of calcium silicate hydrate (C-S-H). The C-S-H gel is in a lamellar (Fig. 7a and 7b) or fibrillar (Fig. 7c and 7d) morphology. This gel was formed by the reaction of calcium hydroxide dissolved in water and the reactive silica present in the ash. 



Figure 7. FESEM micrographs (taken in in-lens mode) of C-S-H morphologies formed EGA-650 particles reacted with calcium hydroxide solution at $65^{\circ} \mathrm{C}$ for 4 days: a) and b) lamellar morphology (Fig $7 \mathrm{~b}$ is an enlarged zone from Fig 7a marked with a dashed rectangle); c) and d) fibrillar morphology (Fig 7d is an enlarged zone from Fig 7c marked with a dashed rectangle) .

The quantification of this reactivity was carried out by means of the assessment of EGA/Ca(OH $)_{2}$ pastes (2:1 ratio by mass with water/solid ratio of 0.8 ). Figure 8 shows the DTG curves obtained for this system after 9 and 28 days of curing, and Table 4 summarizes the most important thermogravimetric parameters. In these DTG curves, three decomposition peaks can be defined. The first one is in the $35-300^{\circ} \mathrm{C}$ range (zone 1), which is attributed to the dehydration of cementing gel of the C-S-H type. This gel was produced by the pozzolanic reaction of reactive silica from the EGA and calcium hydroxide. 

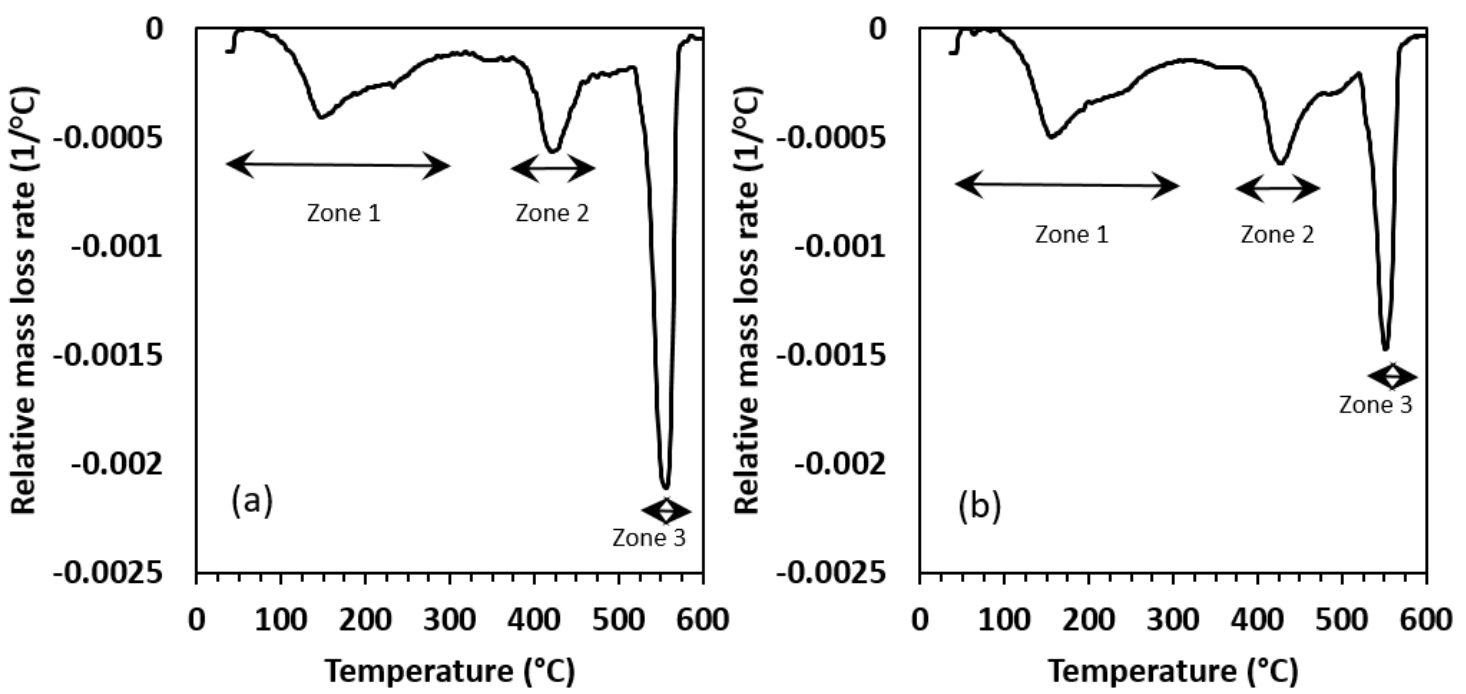

Figure 8. Derivative thermogravimetric curves (DTG) for EGA-Ca(OH $)_{2}$ pastes after a) 9 and b) 28 curing days.

The second peak (in the range of $360-450^{\circ} \mathrm{C}$ ) is attributed to the decomposition of brucite $\left(\mathrm{Mg}(\mathrm{OH})_{2}\right)$. This mineral was produced in the hydration of $\mathrm{MgO}$ (periclase) from the EGA. The amount of brucite, calculated from thermogravimetric curves, is equal (1.53\%, see Table 4) for pastes cured during 9 and 28 days, suggesting that the hydration process of $\mathrm{MgO}$ was completed in few days. XRD pattern of EGA (see Fig. 9) also shows the presence of a small amount of brucite (PDFcard 070239) and an important quantity of periclase (PDFcard 040289). The XRD pattern also shows the presence of potassium salts such as sylvine $\left(\mathrm{KCl}, \mathrm{PDF}\right.$ card 411476) and arcanite $\left(\mathrm{K}_{2} \mathrm{SO}_{4}, \mathrm{PDF}\right.$ ard 050613). Calcium compounds are identified as calcite $\left(\mathrm{CaCO}_{3}, \mathrm{PDF}\right.$ card 050586) and hydroxylapatite $\left(\mathrm{Ca} 5\left(\mathrm{PO}_{4}\right)_{3}(\mathrm{OH})\right.$, PDFcard 090432). No crystallized silicon derived compounds, such as quartz, trydimite and cristobalite were found in the XRD pattern. This means that the silica content in EGA was completely amorphous in nature, and this vitreous phase can react to calcium hydroxide and produce cementing C-S-H gel.

Zone 3 (in the range of $520-580^{\circ} \mathrm{C}$ ) in the DTG curves shows the presence of portlandite, $\mathrm{Ca}(\mathrm{OH})_{2}$, which remained unreacted. It can be highlighted that there is a decrease in the $\mathrm{Ca}(\mathrm{OH})_{2}$ content of the paste from 9 to 28 curing days, suggesting that the pozzolanic reaction takes place, at least, in the first 
28 days. The fixed lime (FL) calculated (Payá et al., 2004) from the remaining calcium hydroxide with respect to the initial one shows that EGA reacted in an important way, representing $35.6 \%$ of fixed lime for 9 days and $63.5 \%$ for 28 days. This increase in FL is related to the formation of more C-S-H, which can be observed as the increment of mass loss in zone $1\left(\mathrm{ML}_{1}\right)$ from 4.96 to $5.75 \%$.

Table 4. Thermogravimetric parameters for EGA:CH (2:1) pastes cured during 9 and 28 days.

\begin{tabular}{|c|c|c|c|c|c|c|c|c|c|c|}
\hline \multirow{2}{*}{$\begin{array}{l}\text { Curing } \\
\text { time } \\
\text { (days) }\end{array}$} & \multirow{2}{*}{$\begin{array}{l}\mathrm{TML}^{\#} \\
(\%)\end{array}$} & \multicolumn{2}{|c|}{ Zone 1} & \multicolumn{3}{|c|}{ Zone 2} & \multicolumn{4}{|c|}{ Zone 3} \\
\hline & & $\begin{array}{c}\mathrm{ML}_{1}{ }^{\mathrm{d}} \\
(\%)\end{array}$ & $\begin{array}{l}\mathrm{TP}_{1}{ }^{*} \\
\left({ }^{\circ} \mathrm{C}\right)\end{array}$ & $\begin{array}{c}\mathrm{ML}_{2}{ }^{\mathrm{d}} \\
(\%)\end{array}$ & $\begin{array}{l}\mathrm{TP}_{2}{ }^{*} \\
\left({ }^{\circ} \mathrm{C}\right)\end{array}$ & $\begin{array}{c}\mathrm{Mg}(\mathrm{OH})_{2} \\
(\%)\end{array}$ & $\begin{array}{c}\mathrm{ML}_{3}{ }^{\mathrm{E}} \\
(\%)\end{array}$ & $\begin{array}{l}\mathrm{TP}_{3}{ }^{*} \\
\left({ }^{\circ} \mathrm{C}\right)\end{array}$ & $\begin{array}{c}\mathrm{Ca}(\mathrm{OH})_{2} \\
(\%)\end{array}$ & $\begin{array}{l}\mathrm{FL}^{* *} \\
(\%)\end{array}$ \\
\hline 9 & 16.26 & 4.96 & 144 & 1.53 & 417 & 4.93 & 5.22 & 547 & 21.46 & 35.6 \\
\hline 28 & 16.09 & 5.75 & 152 & 1.53 & 419 & 4.93 & 2.96 & 549 & 12.17 & 63.5 \\
\hline
\end{tabular}

\# TML: Total Mass Loss $\left(\%, 35-600^{\circ} \mathrm{C}\right.$ range $)$ $\& \operatorname{ML}_{X}(\mathrm{X}=1,2,3)$ : Mass loss $(\%)$ in the zone $\mathrm{X}$ *TPX $(\mathrm{X}=1,2,3)$ : Temperature Peak $\left({ }^{\circ} \mathrm{C}\right)$ for the thermogravimetric event FL**: Fixed lime

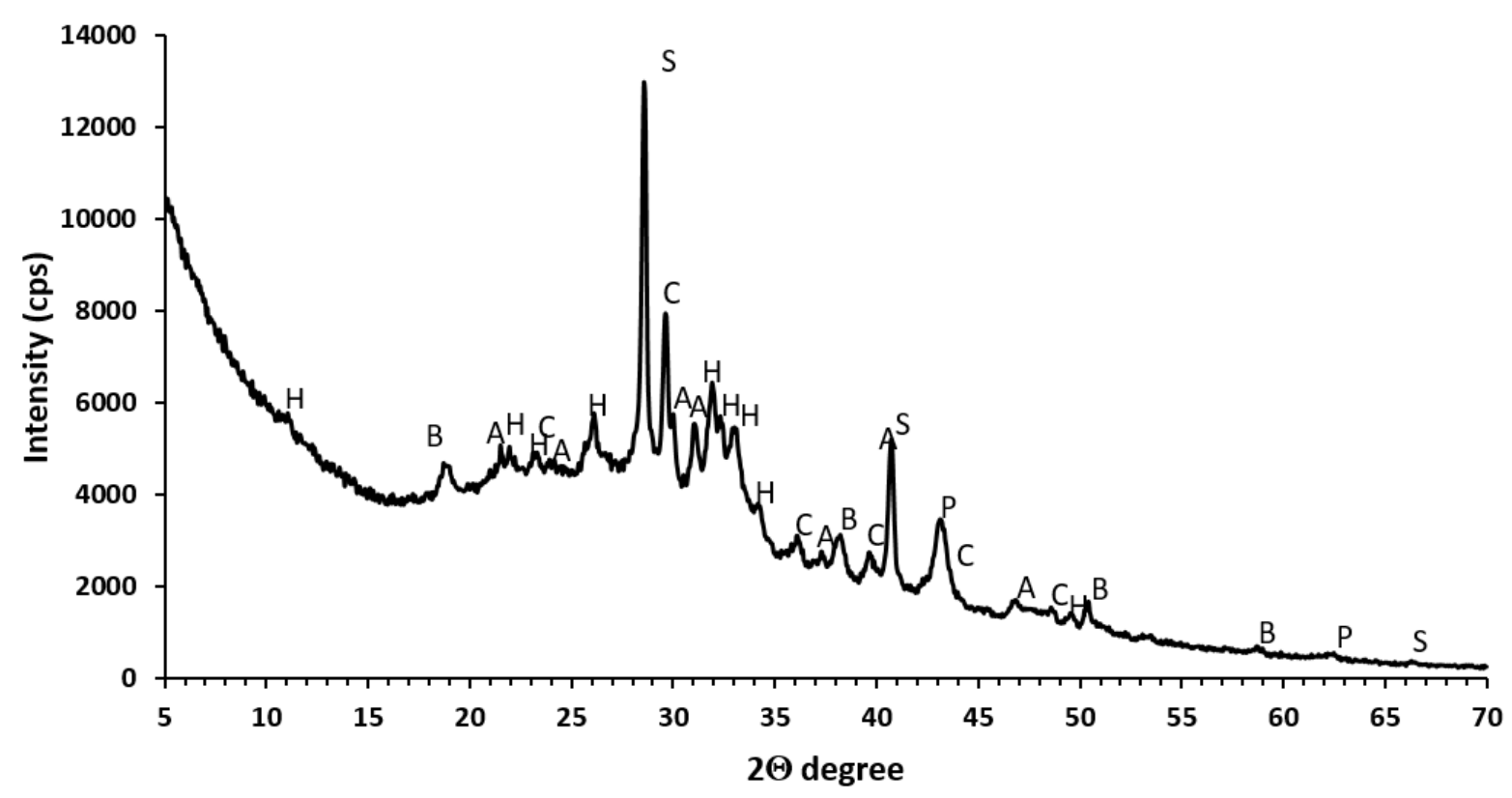

Figure 9. XRD pattern for EGA. Key: C, Calcite; S, Sylvine; A, Arcanite; B， Brucite; H, Hydroxylapatite; P, Periclase.

\section{Conclusions}


Combustion of elephant grass leaves yielded ashes (EGA) that maintained the spodogram (inorganic skeleton after organic matter removal by calcinations) at 450 and $650^{\circ} \mathrm{C}$. At a calcination temperature of $850^{\circ} \mathrm{C}$, the signs of sintering are clearly observed.

Phytoliths (silica bodies with a $\mathrm{SiO}_{2}$ content of 98\%) were present in different shapes (bi-, tri- and tetralobulated) and maintained their shape after calcination without melting after annealing at $650^{\circ} \mathrm{C}$. EDS analyses indicated that hairs also contained a very high silica component (93\%). Magnesium (mainly as periclase) was distributed in the most porous parts in the interior of the leaves. Silica was the main oxide in EGA, reaching more than $70 \%$ by weight. This result shows that EGA would be a good candidate as a pozzolanic mineral addition in OPC mixtures. However, it should be considered that noticeable differences may exist among ashes when comparing results from other papers: depending on the source of leaves and the treatment process, the chemical composition can vary significantly. In this work, negligible contents of aluminium and iron were found, suggesting that previously reported analyses, in which these elements were in significant amount, were taken from soil-contaminated biomass.

It was demonstrated that the high reactivity of EGA, as well as fibrillary and lamellar C-S-H were easily formed by reaction in a calcium hydroxide solution. Fixed lime percentages at 9 and 28 curing days were found to be 35 and $63 \%$ respectively, indicating the high reactivity of EGA in calcium hydroxide pastes due to a pozzolanic reaction.

This study demonstrates the possibility of reusing ashes from elephant grass leaves for producing environmental friendly cements.

\section{Acknowledgements}

The authors would like to thank Electron Microscopy Service of the Universitat Politècnica de València.

\section{References}


Adesanya, D.A. \& Raheem, A.A. (2009). Development of corn cob ash blended cement. Constr Build Mater 23, 347-352. DOI: https://doi.org/10.1016/j.conbuildmat.2007.11.013

Aprianti, E., Shafigh, P., Bahri, S. \& Farahani, J.N. (2015). Supplementary cementitious materials origin from agricultural wastes - A review. Constr Build Mater 74, 176-187. DOI: http://dx.doi.org/10.1016/j.conbuildmat.2014.10.010

Aprianti, E. (2017). A huge number of artificial waste material can be supplementary cementitious material (SCM) for concrete production - a review part II. J Cleaner Produc 142, 4178-4194. DOI: https://dx.doi.org/10.1016/j.jclepro.2015.12.115

Barcelo, L., Kline, L.J., Walenta, G. \& Gartner, E. (2014). Cement and carbon emissions. Mater Struct 47, 1055-1065._DOI: https://doi.org/10.1617/s11527-013-0114-5

Beltran, M.G., Barbudo, A., Agrela, F., Jiménez, J.R. \& de Brito, J. (2016). Mechanical performance of bedding mortars made with olive biomass bottom ash. Constr Build Mater 112, 699-707. DOI: https://doi.org/10.1016/j.conbuildmat.2016.02.065

Cordeiro, G.C. \& Sales, C.P. (2015). Pozzolanic activity of elephant grass ash and its influence on the mechanical properties of concrete. Cem Concr Comp 55, 331-336. DOI:

https://doi.org/10.1016/j.cemconcomp.2014.09.019

Cordeiro, G. \& Sales, C.P. (2016). Influence of calcining temperature on the pozzolanic characteristics of elephant grass ash. Cem Concr Compos 73, 98-104. DOI: https://doi.org/10.1016/i.cemconcomp.2016.07.008

de Souza, M.F., Magalhães, W.L.E. \& Persegil, M.C. (2002). Silica Derived from Burned Rice Hulls. Mat Res 5, 467-474. DOI: http://dx.doi.org/10.1590/S1516-14392002000400012

Flores, R.A., Urquiaga, S., Alves B.J.R., Collier L.S., Boddey R.M. (2012). Yield and quality of elephant grass biomass produced in the cerrados region for bioenergy. Eng. Agríc. 32, 831-839. DOI: http://dx.doi.org/10.1590/S0100-69162012000500003 
Frías, M., Savastano, H., Villar, E., Sánchez de Rojas, M.I. \& Santos, S. (2012). Characterization and properties of blended cement matrices elaborated with activated bamboo leaf wastes, Cem Concr Comp 34, 1019-1023. DOI: https://doi.org/10.1016/j.cemconcomp.2012.05.005

Guzmán, A., Gutiérrez, C., Amigó, V., de Gutiérrez, R.M. \& Delvasto, S. (2011). Pozzolanic evaluation of the sugar cane leaf. Mater Constr 61, 213-225. DOI:http://dx.doi.org/10.3989/mc.2011.54809

Hindryawati, N., Maniam, G.P., Karim, M.R. \& Chong, K.F. (2014).Transesterification of used cooking oil over alkali metal (Li, Na, K) supported rice husk silica as potential solid base catalyst. Eng Sci Technol Int J 17, 95-103. DOI:https://doi.org/10.1016/j.jestch.2014.04.002

Kanning, R.C., Portella, K.F., Bragança, M.O.G.P., Bonato, M.M. \& dos Santos, J.C.M. (2014). Banana leaves ashes as pozzolan for concrete and mortar of portland cement. Constr Build Mater 54, 460-465. DOI: https://doi.org/10.1016/j.conbuildmat.2013.12.030

Lemus, R. \& Lal, R. (2007). Bioenergy crops and carbon sequestration. Critical Rev Plant Sciences 24, 1-21. DOI:https://doi.org/10.1080/07352680590910393

Lima, S.A. \& Rossignolo, J.A. (2009). Analysis of pozzolanicity of the rind cashew nut ashes by Xray diffraction. Revi Mat 14, 680-688 (in portuguese). DOI: http://www.materia.coppe.ufrj.br/sarra/artigos/artigo11003

Moraes, J.C.B., Akasaki, J.L., Melges, J.L.P., Monzó, J., Borrachero, M.V., Soriano, L., Payá, J. \& Tashima, M.M. (2015). Assessment of sugar cane straw ash (SCSA) as pozzolanic material in blended Portland cement: Microstructural characterization of pastes and mechanical strength of mortars. Constr Build Mater 94, 670-677. DOI: https://doi.org/10.1016/j.conbuildmat.2015.07.108

Nakanishi, E.Y., Frías, M., Martínez-Ramírez, S., Santos, S.F., Rodrigues, M.S., Rodríguez, O. \& Savastano Jr, H. (2014a). Characterization and properties of elephant grass ashes as supplementary cementing material in pozzolan/Ca(OH) 2 pastes. Constr Build Mater 73, 391-398. DOI: https://doi.org/10.1016/j.conbuildmat.2014.09.078 
Nakanishi, E.Y., Villar-Cociña, E., Santos, S.F., Rodrigues, M.S., Pinto P.S. \& Savastano Jr, H. (2014b). Thermal and chemical treatments for removal of alkali oxides of elephant grass ashes. Quim Nova 37, 766-769 (in portuguese). DOI: https://doi.org/10.5935/0100-4042.20140123

Nakanishi, E.Y., Frías, M., Santos, S.F., Rodrigues, M.S., Villa, R.V.V., Rodriguez, O. \& Savastano Jr, H. (2016). Investigating the possible usage of elephant grass ash to manufacture the eco-friendly binary cements. J Cleaner Produc 116, 236-243. DOI: https://doi.org/10.1016/j.jclepro.2015.12.113 Payá, J., Monzó, J., Borrachero, M.V. \& Velázquez, S. (2004). Chemical activation of pozzolanic reaction of fluid catalytic cracking catalyst residue (FOR) in lime pastes: thermal analysis. Advan Cem Res 16, 123-130. DOI: https://doi.org/10.1680/adcr.2004.16.3.123

Payá, J., Monzó, J. \& Borrachero, M.V. (2010). Outstanding aspects on the use of rice husk ash and similar agrowastes in the preparation of binders. In Proceedings of the First Pro-Africa Conference: Non Conventional Building Materials Based on Agroindustrial Wastes, Savastano Jr. H. (Ed.), pp. 179-181. São Paulo, Brazil: Pirassununga.

Piperno, D.R. (2006). Phytoliths: A Comprehensive Guide for Archaeologists and Paleoecologists. AltaMira Press, Oxford.

Prychid, C.J., Rudall, C.P.J. \& Gregory, M. (2003). Systematics and biology of silica bodies in monocotyledons, Bot Rev 69, 377-440. DOI: http://dx.doi.org/10.1663/00068101(2004)069[0377:SABOSB]2.0.CO;2

Rodier, L., Bilba, K., Onésippe, C. \& Arsène, M.A. (2017) Study of pozzolanic activity of bamboo stem ashes for use as partial replacement of cement. Mater Struct 50, 87. DOI: https://dx.doi.org/10.1617/s11527-016-0958-6

Rivas A.L., Vera G., Palacios V., Cornejo M., Rigail A. \& Solórzano G. (2018). Phase Transformation of Amorphous Rice Husk Silica. In Frontiers in Materials Processing, Applications, Research and Technology, Muruganant M., Chirazi A. \& Raj B. (Eds.), pp. 17-26. Springer, Singapore. 
Rocha, J.R.A.S.C., Machado, J. C., Carneiro, P.C.S., Carneiro, J. C., Vilela Resende, M. D. \& Carneiro, J.E.S. (2017). Elephant grass ecotypes for bioenergy production via direct combustion of biomass. Ind Crops Prod 95, 27-32. DOI: https://doi.org/10.1016/j.indcrop.2016.10.014

Roselló, J., Soriano, L., Santamarina, M.P., Akasaki, J.L., Melges, J.L.P. \& Payá, J. (2015). Microscopy Characterization of Silica-Rich Agrowastes to be used in Cement Binders: Bamboo and Sugarcane Leaves. Microsc Microanal 21, 1314-1326. $\quad$ DOI: http://dx.doi.org/10.1017/S1431927615015019

Sata, V., Tangpagasit, J., Jaturapitakkul, C. \& Chindaprasirt, P. (2012). Effect of W/B ratios on pozzolanic reaction of biomass ashes in Portland cement matrix. Cem Concr Comp 34, 94-100. DOI: https://doi.org/10.1016/j.cemconcomp.2011.09.003

Siddique, R. \& Khan, M.I. (2011). Supplementary Cementing Materials, Springer Science \& Business Media. DOI: http://dx.doi.org/10.1007/978-3-642-17866-5

Silva, R.B., Fontes, C.M.A., Lima, P.R.L., Gomes, O.F.M., Lima, L.G.L. M., Moura, R.C. A. \& Toledo Filho, R.D. (2015). Biomass ash from cocoa agroindustry: characterization and use as a cement substitute. Ambient Constr 15, 321-334 (in portuguese). DOI: http://dx.doi.org/10.1590/s1678-86212015000400053

Villar-Cociña, E., Valencia Morales, E., Santos, S.F., Savastano Jr, H. \& Frías, M. (2011). Pozzolanic behaviour of bamboo leaf ash: Characterization and determination of the kinetic parameters. Cem Concr Comp 33, 68-7. DOI:10.1016/j.cemconcomp.2010.09.003 